\title{
PENGGUNAAN FITUR E-ZAKAT SEBAGAI MEDIA PENYALURAN HASIL ZAKAT FITRAH KEPADA MUSTAHIQ
}

\author{
Muhamad Awiet Wiedanto Prasetyo ${ }^{1}$, Indika Manggala Putra ${ }^{2}$, Rizky Bangkit Bachtiar ${ }^{3}$, \\ Laely Candra Arviana ${ }^{4}$, Ajiono ${ }^{5}$ \\ 1,2,3,4,5 Prodi Sistem Informasi, Fakultas Ilmu Komputer, Universitas Amikom Purwokerto, Indonesia \\ ${ }^{1}$ mawp@amikompurwokerto.ac.id, ${ }^{2}$ impbarca046@gmail.com, ${ }^{3}$ rizkybangki13@gmail.com, \\ 4arviilaely@gmail.com, 5 ajiy251@gmail.com
}

\begin{abstract}
ABSTRAK
Untuk mempermudah kegiatan proses penghimpunan, mengelola dan penyaluran zakat, badan amil zakat fitrah Masjid Baitul Yamin membagikan tugas badan amil harus ada ditingkat dusun dan rukun warga dikarenakan memiliki jarak saling berjauhan dan melewati akses jalan desa atau jalan kabupaten untuk menuju pusat desa. Dengan permasalahan tersebut, terdapat fasilitas yang menunjang seperti akses jaringan provider berbasis $4 \mathrm{G}$ yang memudahkan komunikasi lebih lancar namun masih mengalami kendala saat perhitungan hasil akhir yang mengakibatkan kesalahan penerimaan oleh mustahiq. Metode penelitiannya adalah ketua tim melakukan wawancara kepada kepala desa dan perangkat desa untuk mengetahui permasalahan yang ada dimasyarakat yang nantinya bisa diselesaikan dengan pemfantaan teknologi informasi. Kemudian ketua tim melakukan wawancara kembali kepada ketua panitia Badan Amil Zakat Masjid Baitul Yamin untuk mendapatkan informasi kendala saat berlangsungnya kegiatan zakat fitrah setiap tahunnya dan merumuskan permasalahan yang ada segera terselesaikan. Dengan Fitur E-Zakat yang sudah dihasilkan sangatlah bermanfaat bagi badan amil zakat Desa Kedunggede dalam membantu pelaksanaan pendataan dan pembagian zakat fitrah. Dengan adanya tampilan yang sederhana membantu para badan zakat memahami cara mengoprasikan aplikasi zakat yang sudah di buat dari mulai login hingga menginputkan data siapa saja yang mendapatkan zakat serta mempresentase zakat yang didapatkan oleh setiap mustahiq.
\end{abstract}

Kata Kunci-Zakat FItrah, Mustahiq, E-Zakat.

\begin{abstract}
In order to facilitate the process of collecting, managing and distributing zakat, the amil zakat fitrah Baitul Yamin Mosque distributes the amil body's tasks to be at the hamlet and community level because they have a distance from each other and pass through village or regency road access to the village center. With these problems, there are supporting facilities such as $4 G$ base provider network access that facilities smoother communication but still experiences problems when calculating the final result that results in an error of acceptance by mustahiq. The research method is that the team leader conducts an interview with the village apparatus to find out the problems that exist in the community which can later be solved by using information technology. Then the team leader conducts an interview again to the chairman of the committee of the Baitul Yamin Mosque Amil Zakat Board to get information on the constraints during the zakat fitrah activities each year and to formulate the existing problems immediately resolved. The E-Zakat feature that has been produced is very beneficial for the amil zakat body of Kedunggede Village is assisting the data collection and distribution of zakat fitrah. With a simple display that helps the zakat bodies understand how to operate the zakat application that has been made from the login to enter the data of who gets zakat and the percentage of zakat obtained by each mustahiq.
\end{abstract}

Keywords-Zakat Fitrah, Mustahiq, E-Zakat. 


\section{PENDAHULUAN}

Agama Islam memiliki dua pilar penting yang menjadi pedoman kehidupan sebagai muslim yaitu Rukun Iman dan Rukun Islam. Rukun Iman terdiri dari Iman Kepada Allah, Iman Kepada Para Malaikat, Iman Kepada Kitab-Kitab Allah, Iman Kepada Nabi dan Rasul, Iman Kepada Hari Kiamat dan Iman Kepada Qada dan Qodar, sedangkan Rukun Islam terdiri dari Mengucapkan Kalimat Syahadat, Mendirikan Shalat, Menunaikan Zakat, Menjalankan Perintah Puasa Bulan Ramadhan dan Menunaikan Ibadah Haji bagi yang mampu. Rukun Islam ketiga, zakat terbagi menjadi dua yaitu Zakat Maal adalah zakat penghasilan yang diperoleh dari hasil pertanian, hasil pertambangan, hasil laut, hasil perdagangan, hasil ternak, harta temuan, emas dan perak [1], sedangkan Zakat Fitrah adalah zakat pribadi yang diwajibkan atas diri setiap muslim yang memiliki syarat-syarat yang diterapkan untuk ditunaikan pada bulan ramadhan sampai menjelang shatlat sunnah idul fitri [2]. Zakat disalurkan oleh mushola atau masjid dan badan-badan amal zakat yang ada disekitar kita atau disekitar tempat yang berhak menerima zakat.

Badan amil zakat Masjid Baitul Yamin adalah badan amil yang bertugas untuk menghimpun dan mengelola zakat fitrah khususnya Wilayah Desa Kedunggede Kecamatan Lumbir Kabupaten Banyumas sekaligus letak geografisnya berdekatan dengan Kantor Pemerintah Desa Kedunggede. Kegiatan pertama panitia amil zakat adalah mendata warga yang berhak menerima seperti fakir, miskin, amil, mu'allaf, riqab, gharim, fisabilillah dan ibnu sabil. Selanjutnya jenis zakat yang harus dikeluarkan oleh muzakki berupa uang tunai dan beras. Untuk mempermudah kegiatan proses penghimpunan, mengelola dan penyaluran zakat, panitia amil zakat fitrah Masjid Baitul Yamin membagikan tugas setiap pos amil harus ada ditingkat dusun dan rukun warga sesuuai dengan Gambar 1. Denah Amil Desa Kedunggede, yang memiliki jarak saling berjauhan dan melewati akses jalan desa atau jalan kabupaten untuk menuju pusat desa. Kemudian setiap pos amil wajib melaporkan hasil penghimpunan untuk diketahui dan ditanda tangani terlebih dahulu oleh ketua panitia yang ada di Masjid Baitul Yamin sebelum disalurkan kepada mustahiq.

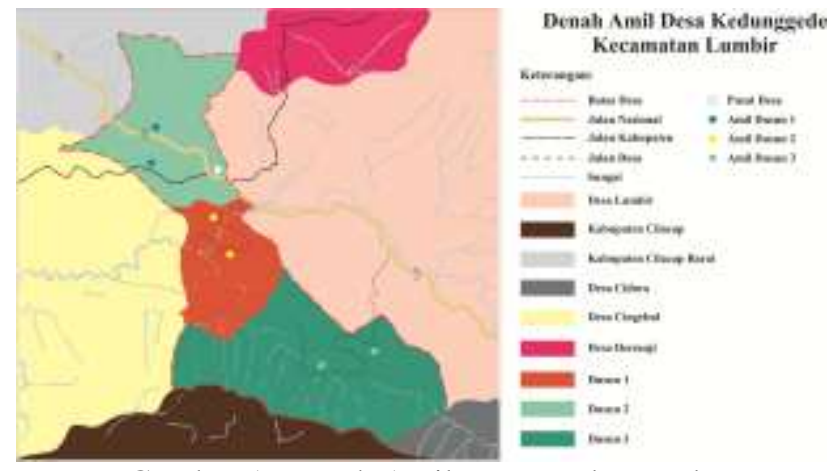

Gambar 1. Denah Amil Desa Kedunggede

Dengan permasalahan diatas, ada fasilitas yang menunjang seperti akses jaringan provider berbasis $4 \mathrm{G}$ yang memudahkan komunikasi lebih lancar. Panitia Badan Amil Masjid Baitul Yamin sudah memanfaatkan teknologi tersebut dengan melaporkan hasil penghimpunan secara bertahap, namun mengalami kendala saat perhitungan hasil akhir yang berubah-ubah, maka mengakibatkan kesalahan yang harus diterima oleh mustahiq. Perkembangan teknologi informasi saat ini sudah mengalami kemajuan yang sangat pesat. Kebutuhan masyarakat akan kemudahan proses pada segala bidang kerja semakin meningkat untuk dimanfaatkan pengolahan data karena banyak memiliki keuntungan seperti kecepatan, keakuratan serta efisien yang dibandingkan dengan cara konvensional. Perkembangan teknologi yang saat ini sedang mengalami kemajuan yang sangat pesat adalah pemanfaatan teknologi mobile dengan sistem operasi android. Android merupakan sistem operasi bersifat open source berbasis linux untuk perangkat seluler layar sentuh seperti smartphone dan komputer tablet. Terdapat penelitian yang memanfaatkan android sebagai media informasi zakat yang mempermudah dan mempercepat melakukan proses perhitungan dan membantu penyaluran zakat fitrah yang memperoleh kesimpulan aplikasi zakat tersebut dapat diterima oleh para pengguna [3].

Dari permasalahan diatas, peneliti memiliki tujuan untuk menghasilkan aplikasi mobile untuk memudahkan pengolahan data hasil zakat fitrah yang dapat digunakan setiap pos-pos amil tersebar Wilayah Desa Kedunggede yang saling terhubung satu dengan lainnya

\section{TINJAUAN PUSTAKA}

\subsection{Tinjauan Pustaka}

Zakat fitrah adalah kadar harta tertentu atau memiliki kelebihan bahan makanan yang harus diberikan kepada kelompok-kelompok tertentu dengan berbagai syarat [4]. Zakat fitrah wajib dibayar oleh seseorang pada saat bertepatan dengan berbuka puasa pada akhir puasa ramadhan [5]. Zakat fitrah dibayar seseorang dengan kadar zakatnya $2,5 \mathrm{~kg}$ bahan makanan pokok atau dibayar dengan uang yang memiliki nilai setara dengan zakat tersebut.

Android merupakan sistem operasi berbasis linux yang dapat digunakan perangkat mobile [6]. Android menyediakan platform terbuka bagi para pengembang untuk menciptakan aplikasi mereka sendiri untuk digunakan oleh bermacam piranti bergerak [7]. Android memiliki karakteristik terbuka, semua aplikasi dibuat sama, memecahkan hambatan dan pengembangan aplikasi yang cepat dan mudah [8]. Kesimpulan android adalah sistem operasi menggunakan linux yang sedang berkembang ditengah sistem operasi lainnya.

Aplikasi mobile adalah sebuah aplikasi yang memungkinkan anda melakukan mobilitas dengan perlengkapan seperti PDA, telepon seluler [9]. Perangkat lunak yang berjalan pada perangkat mobile seperti smartphone atau tablet PC [10]. Aplikasi mobile juga dijkenal sebagai aplikasi yang dapat diunduh dan memiliki fungsi tertentu sehingga menambahkan fungsional dari perangkat mobile itu sendiri [11]. Aplikasi yang dapat digunakan walaupun pengguna berpindah dari suatu tempat ke tempat yang lain tanpa terjadi pemutusan atau terputusnta komunikasi. Dengan menggunakan aplikasi 
mobile, anda dapat dengan mudah melakukan berbagai macam aktifitas mulai dari hiburan, berjualan, belajar, mengerjakan pekerjaan kantor dan lainnya.

Penelitian lain yang menghasilkan penggunaan aplikasi dapat menyimpan data dan menghitung secara automatis oleh sistem sehingga para panitia amil zakat tidak perlu menghitung secara konvensional. Kekurangannya adalah terjadi kesalahan pada aplikasi saat tidak mengisi filed data terlebih dahulu dan dibatasi sebanyak 12 kali penyimpanan data setiap harinya [12]. Penelitian kedua aplikasi dapat dijalankan pada perangkat android minimal versi android 7.0 Nougat yang mengakibatkan pengguna harus memiliki jenis smartphone terbaru untuk menjalankan aplikasi tersebut [13]. Penelitian ketiga membuktikan aplikasi zakat fitrah data membantu setiap orang untuk melaksanakan kegiatan zakatnya baik zakat fitrah, zakat maal, zakat profesi dan fidyah [14].

\section{METODE YANG DIUSULKAN}

Penelitian yang dilakukan merupakan pengembangan sistem. Tahapan yang dilakukan yaitu dengan melakukan analisis, perencangan, dan implementasi. Metode pendekatan yang digunakan dalam penelitian ini yaitu pengembangan model air terjun (waterfall). Berdasarkan Gambar 2. Tahapan analisis sistem merupakan tahapan mengenali sistem yang akan dibangun. Pada tahapan ini teknik yang digunakan adalah teknik pengumpulan data dengan cara observasi dan wanwancara serta melakukan studi pustaka dari penelitian rancangan bangun aplikasi android. Dari data analisis yang didapat, akan digunakan sebagai dasar dalam perancangan aplikasi yang akan dibuat.

Tahapan selanjutnya merancang sistem pada penelitian ini menggunakan permodelan sistem UML (Unified Modeling Language), meliputi use case diagram, class diagram, activity diagram, dan sequence diagram. Tahapan terakhir adalah implementasi dengan menggunakan flutter untuk antarmuka aplikasi android, Software Development Kit (SDK) merupakan tools Aplication Programming Interface (API) yang diperlukan untuk memulai mengembangkan aplikasi. Pada platform Android menggunakan Flutter, serta Android Studio atau Teks Editor untuk pembuatan Interface dan fungsi-fungsi pada aplikasi zakat yang akan dibuat. Selian itu sistem pada penelitian ini juga terintegrasi dengan web admin yang dibangun menggunakan bahasa pemrograman Hypertext Preprocessor (PHP) dengan framework Laravel.

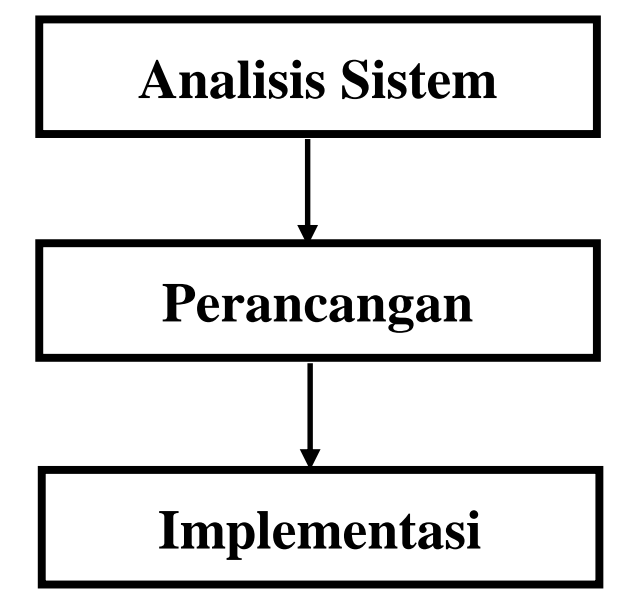

Gambar 2. Alur metode pengembangan sistem

\section{HASIL PENELITIAN}

Setelah melakukan tahap penelitian, berikut merupakan hasil dan pembahasan dari penelitian yang dilakukan:

\subsection{Analisis Sistem}

Ketua tim melakukan wawancara dengan kepala desa dan perangkat desa untuk mengetahui permasalahan yang ada dimasyarakat yang nantinya bisa diselesaikan dengan pemfantaan teknologi informasi. Berdasarkan hasl wawancara, saat ini Badan Amil Zakat Desa Kedunggede masih menggunakan penulisan manual dan pengumpulan data semua amil zakat berpusat di Balai desa Kedunggede. Ketua tim juga melakukan wawancara kembali dengan ketua Badan Amil Zakat Masjid Baitul Yamin untuk mendapatkan informasi kendala yang dialami secara langsun berdasarkan kegiatan zakat fitrah setiap tahunnya. Hasl wawancara didapatkan data bahwa jarak antara pos amil dengan balaidesa yang lumayan berjauhan, hal ini menyebabkan perhitungan zakat berlangsung lama, karna harus menunggu panitia amil berkumpul semua di balaidesa.

\subsection{Perancangan}

Penelitian ini menggunakan UML (Unified Modeling Language) sebagai permodelan sistem. Unified modeling Langguage (UML) adalah "bahasa standar untuk penulisan cetak biru perangkat lunak atau blueprint. UML dapat digunakan untuk memvisualisasikan, menentukan, mengonstruksi, dan mendokumentasikan artefak-artefak suatu system Software intensive" [15]. Model UML yang digunakan terdiri dari use case diagram, class diagram, activity diagram, dan sequence diagram.

\subsubsection{Use Case Diagram}

Use case Diagram digunakan untuk menggambarkan sistem dari sudut pandang pengguna sistem tersebut (user). sehingga pembuatan use case diagram lebih dititik beratkan pada fungsionalitas yang ada pada sistem, bukan berdasarkan alur atau urutan kejadian. Sebuah use case diagram mempresentasikan sebuah interaksi antara aktor 
Jurnal Ilmiah Ilmu Komputer Vol. 6, No. 2, April 2020

Fakultas Ilmu Komputer

Universitas AL Asyariah Mandar

dengan sistem [16]. Berikut merupakan use case diagram sistem yang dibangun :

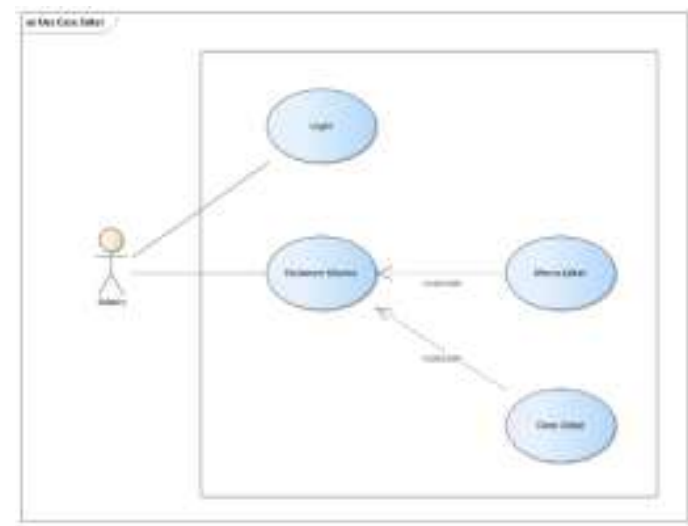

Gambar 3. Use Case Admin Zakat

Berdasarkan Gambar 3. Menjelaskan admin zakat akan login dengan username dan password yang sudah ditentukan. Disaat username dan password sesuai akan masuk ke halaman utama dan dapat mengakses menu zakat dan data zakat.

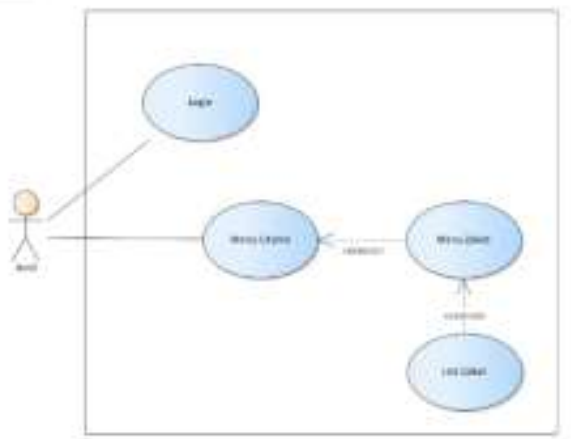

Gambar 4. Use Case Amil Zakat

Berdasarkan Gambar 4. Menjelaskan admin zakat akan login dengan username dan password yang sudah ditentukan oleh penulis. Disaat username dan password sesuai akan masuk ke halaman utama dan dapat mengakses menu zakat dan list zakat.

\subsubsection{Class Diagram}

Class Diagram menggambarkan keadaan (atribut atau properti) suatu sistem, sekaligus menawarkan layanan untuk memanipulasi keadaan tersebut (metode atau fungsi) [16].

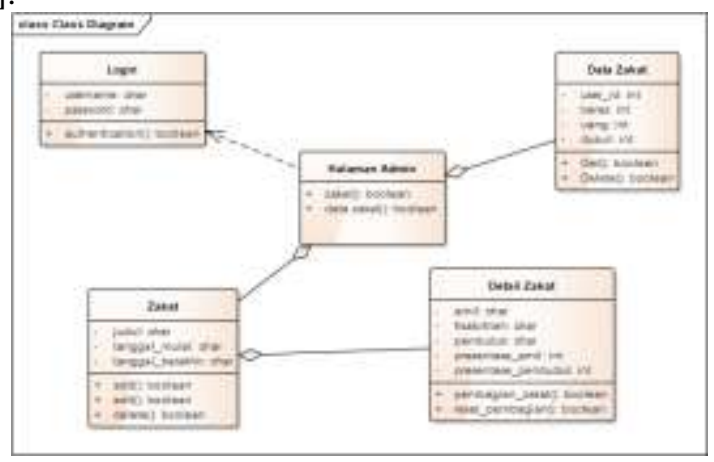

Copyright () 2020 FIKOM - UNASMAN

http://ejournal.fikom-unasman.ac.id
(P) ISSN 2442-451X

(O) ISSN 2503-3832

\section{Gambar 5. Class Diagram Zakat}

Berdasarkan Gambar 5. Menjelaskan menu login memiliki atribut username dan password yang semuanya bersifat char selanjutnya terhubung ke menu halaman utama. Pada menu halaman utama mempunyai atribut zakat dan data zakat yang semuanya bersifat Boolean dengan relasi menu zakat dan data zakat. Kemudian menu data zakat memiliki atribut user id, beras, uang dan dusun bersifat integer. Selanjutnya dimenu zakat memiliki relasi detail zakat, menu zakat memiliki atribut judul, tanggal mulai dan tanggal berakhir bersifat chat. Menu detail zakat memiliki atribut amil, fisabilillah, penduduk dengan bersifat char dan presentase amil dan presentase penduduk bersifat integer.

\subsubsection{Activity Diagram}

Activity diagram menggambarkan rangkaian aliran dari aktivitas, digunakan untuk mendeskripsikan aktifitas yang dibentuk dalam suatu operasi sehingga dapat juga digunakan untuk aktifitas lainnya [16].

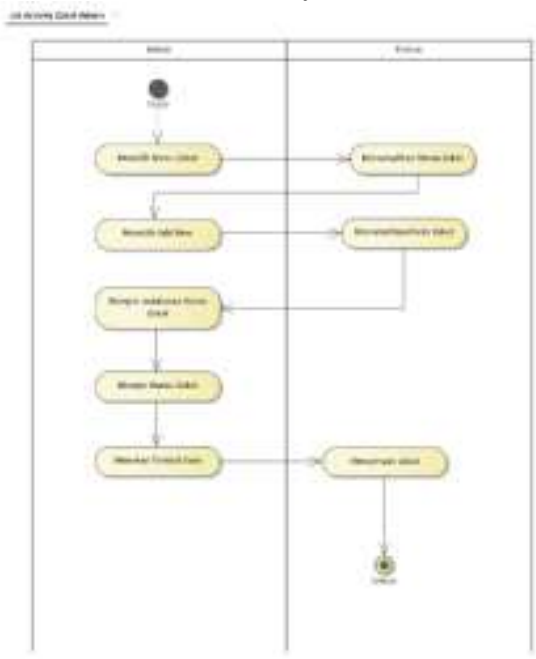

Gambar 6. Activity diagram zakat admin

Berdasrkan Gambar 6. Menjelaskan aktivitas admin dapat melakukan pengisian jenis zakat, mengisi judul serta nama zakat, dan durasi pengisian zakat secara sistem.

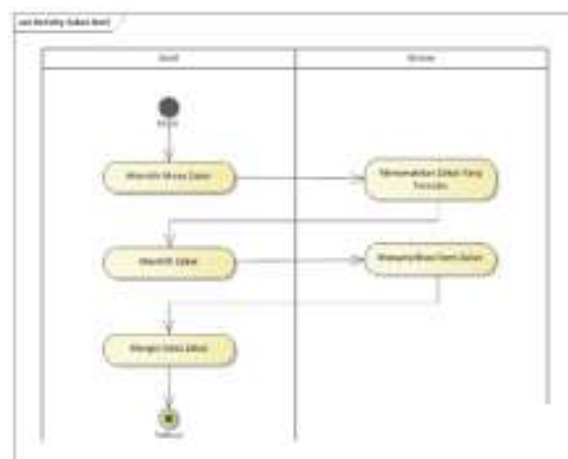

Gambar 7 Activity diagram zakat amil 
Berdasarkan Gambar 7. menjelaskan aktivitas amil hanya memilih judul zakat dan pengisian formulir zakat yang nantinya akan terkirim ke menu admin.

\subsubsection{Sequence Diagram}

Sequence diagram menggambarkan interaksi antara sejumlah objek dalam urutan waktu. Kegunananya untuk menunjukan rangkaian pesan yang dikirim antara objek juga interaksi antar objek yang terjadi pada titik tertentu dalam eksekusi sistem [16].

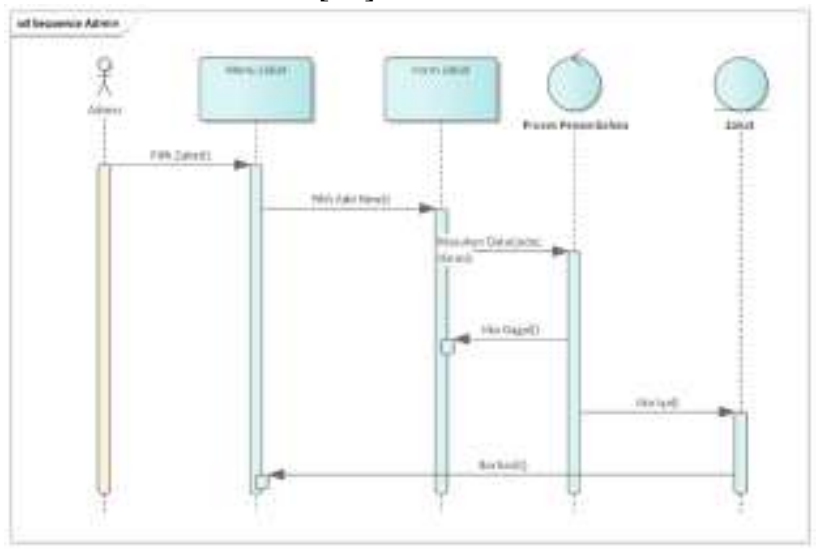

Gambar 8. Sequence diagram admin

Berdasarkan Gambar 8. Menjelaskan intraksi antara objek untuk user admin. Disaat admin memilih menu zakat akan muncul fitur add new yang digunakan menambah kegiatan zakat dengan judul baru, selanjutnya mengisi formulir dari judul kegiatan zakat (sample: Zakat Amil Dusun 1) kemudian menentukan durasi waktu pengisian pada sistem agar nantinya amil tidak melewati batas waktu yang sudah ditentukan.

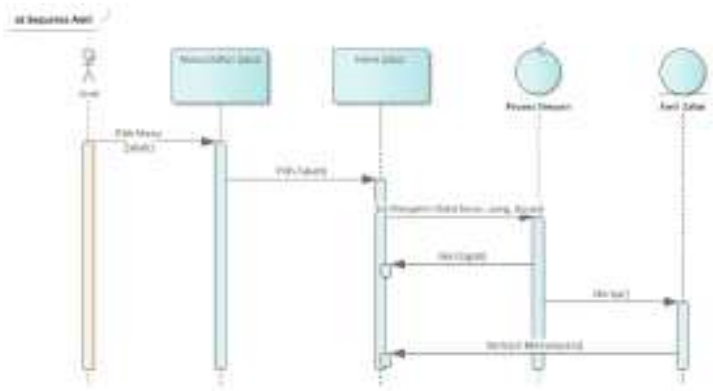

Gambar 9. Sequence diagram amil

Berdasarkan Gambar 9. Menjelaskan intraksi antara objek untuk user amil. Disaat amil memilih menu zakat akan muncul fitur Daftar Nama Zakat (sample: Zakat Amil Dusun 1), setelah memilih nama zakat akan tampil Form Zakat yang digunakan pengisian formulir berupa nama, bentuk zakat (Uang / Beras) dan Alamat. Namun apabila akan melakukan penginputan tidak terdapat nama zakat, maka sudah dipastikan melewati batas durasi waktu yang ditentukan.

\subsection{Implementasi}

Tahapan terkahir adalah mengimplementasikan semua perancangan yang sudah dibuat dan terbentuklah aplikasi dengan antar muka sebagai berikut:

\subsubsection{Tampilan Android}

a) Menu Zakat

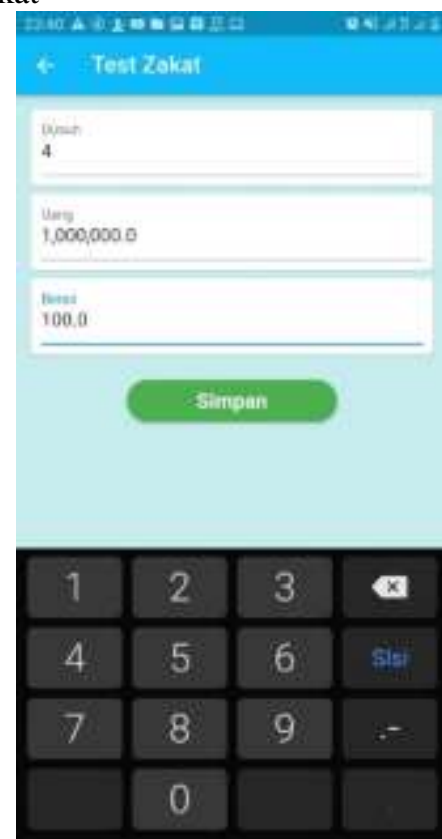

Gambar 10. Tampilan Form Zakat Pada Android

Berdasarkan Gambar 10. menjelaskan formulir zakat yang digunakan untuk penginputan jumlah zakat oleh amil dari setiap dusun yang telah terkumpul pada setiap pos amil. Menu login yang digunakan untuk login amil, dengan cara memasukan username dan kata sandi yang sudah terdaftar pada database.

\subsubsection{Tampilan Web}

a) Tampilan Fitur Zakat

Fitur pada menu zakat ada bermacam-macam diantaranya membuat data zakat, dan perhitungan zakat. Fitur menu zakat diantaranya yaitu membuat data zakat baru, detail zakat, edit zakat, dan hapus zakat. Pembuatan data zakat baru, admin harus mingisikan judul dan tanggal mulai zakat hingga penutupan zakat. Untuk mengetahui hasil pembagian zakat, admin harus menekan tombol detail pada menu zakat, dan otomatis akan dialihkan ke menu pembagian zakat, admin wajib memasukan data penerima zakat, presentase penerima zakat, penerima amil, presentase amil, dan penerima fisabilillah sesuai dengan Gambar 11 .

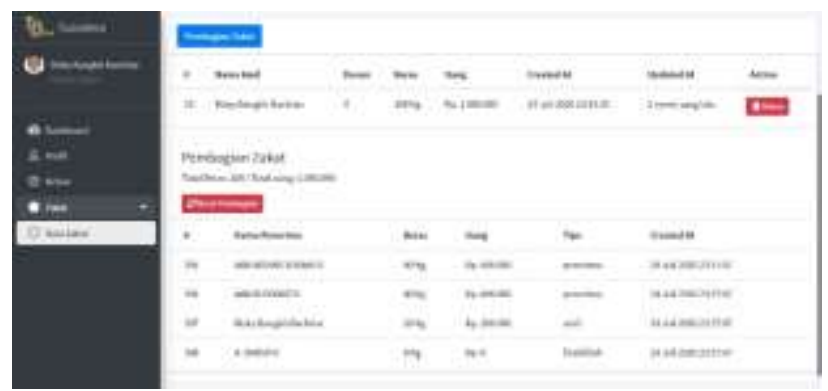


Jurnal Ilmiah Ilmu Komputer Vol. 6, No. 2, April 2020

Fakultas Ilmu Komputer

Universitas AL Asyariah Mandar

Gambar 11. Tampilan perhitungan zakat pada web

\section{KESIMPULAN}

Kesimpulan penelitian saat ini adalah menghasilkan aplikasi zakat fitrah berbasis android yang digunakan oleh badan amil zakat dan website sebagai administrator yang dikelola oleh ketua Badan Amil Zakat Masjid Baitul Yamin. Fitur E-Zakat dengan tampilan yang sederhana membantu para badan zakat memahami cara mengoprasikan dari mulai login hingga menginputkan data siapa saja yang mendapatkan zakat serta mempresentase zakat yang didapatkan oleh setiap mustahiq. Diharapkan denga adanya fitur E-Zakat ini Badan Amil Zakat Masjid Baitul Yamin Desa Kedunggede dapat meningkatkan pelayanan dalam bidang zakat fitrah setiap tahunnya.

\section{UCAPAN TERIMA KASIH}

Penulis mengucapkan terimakasih kepada Universitas Amikom Purwokerto yang telah mendanai Skim Amikom Mitra Masyarakat Tahun Anggaran 2020.

\section{Daftar Pustaka}

[1] M. Novia, Nely., Noor, Iswan., dan., Ekawaty, "Analisis Pengaruh Faktor Non-Ekonomi Terhadap Sikap Pedagang Madura Dalam Membayar Zakat Perdagangan," J. Al-Muzara'ah, vol. 6, 2018.

[2] R. Idayanti, "Distribusi Zakat Fitrah Pada Masyarakat Miskin Kecamatan Tanete Riattang Barat," Iltizam J. Shariah Econ. Res., vol. 2, 2018.

[3] A. Ihsanudin., Renadi, Eko., dan., Setia, "Pengembangan Aplikasi Perhitungan Zakat Berbasis Android," Algoritma, vol. 10, 2013.

[4] S. Hidayat, Akik., dan., Fahri, "Perancangan Sistem Informasi Pengolahan Data Zakat Fitrah Berdasarkan Perhitungan Badan Amil Zakat," Manaj. Inform., vol. 4, 2017.

[5] B. R. N. Fahmy, "Rancang Bangun Aplikasi Penerima Zakat Berbasis Android Menggunakan Metode Simple Additive Weighting Studi Kasus Lembaga Kajian Zakat dan Wakaf Universitas Islam Negeri Maulana Malik Ibrahim Malang," Islam Negeri Maulana Malik Ibrahim, 2015.

[6] N. R. Nurfadillah., dan., Kurnianda, "Analisa dan Perancangan Aplikasi Pengolahan Sampah Rumah Tangga Berbasis Android," Ilm. FIFO, vol. 11, 2019.

[7] L. Rahmelina, "Perancangan Mobile Learning Berbasis Android Pada Mata Kuliah Sistem Operasi Di STMIK Indonesia Padang," Informatika, vol. 11, 2017.

[8] B. A. Mahara, Rike., dan., Majid, "Perancangan Interface Aplikasi E-Skripsi Berbasis Android," Pendidik. Teknol. Inf., vol. 2, 2018.

[9] R. N. Kosidin., dan., Farizah, "Pemodelan Aplikasi Mobile Reminder Berbasis Android," Seminar Nasional Teknologi Informasi dan Komunikasi, Yogyakarta, Mar-2016.
(P) ISSN 2442-451X

[10] R. Hariyanto, Abdul., Sugiharti, Endang., dan., Arifudin, "Aplikasi Mobile Sistem Informasi Akademik Labschool Universitas Negeri Semarang Berbasis Android," UNNES Jouornal Math., vol. 8, 2019.

[11] Y. M. Ramadhan, “Aplikas Informasi Transformasi Angkutan Umum Antar Kota Pada Terminal Amplas SUmatra Utara," Sist. Inf. dan Teknol., vol. 1, 2018.

[12] H. P. Ramadan, "Aplikasi Perhitungan dan Pencatatan Zakat Sesuai Nisab dan Haul," Universitas Islam Indonesia, 2018.

[13] H. Mirtasari, Desiana., dan., Februariyanti, "Perhitungan Zakat Harta dan Zakat Profesi Berbasis Android," Seminar Nasional Teknologi Informasi Dan Aplikasi Komputer, Semarang, Nov2018.

[14] M. Syakirin, "Perancangan Aplikasi Perhitungan dan Pembayaran Zakat Berbasis Android Di Yayasan Lazis Amaliah Astra," AMIK BSI, 2016.

[15] S. Pressman, Roger, Rekayasa Perangkat Lunak Pendekatan Praktisi, 7th ed. Yogyakarta: Andi Offset, 2012.

[16] I. G. Tofik and G. P. Hartawan, "Perancangan Aplikasi Koperasi Simpan Pinjam Berbasis Web (Studi Kasus Koperasi Mitra Setia),' J. Ilm. Ilmu Ekon., vol. 5, no. 10, pp. 139-151, 2017. 